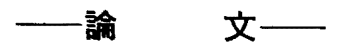

（日本化学会誌，1988，(12), p. 1984 1990)

(C) 1988 The Chemical Society of Japan

\title{
2-ピロンおよびその置換体とマレイミド類の
}

\section{$[4+2]$ 付加反応および付加体の安定性}

(1988 年 6 月 3 日受理)

下，茂徽朗・吉村浩幸・水主高昭・染川賢一*

2-ピロンおよびその置換体の [4+2] 付加反応性および付加体の安定性を明らかにする目的で， 4 種 の 2-ピロン類と $N$-置換マレイミドとの反応を行ない $1: 1$ endo 付加体 [1]，拈よび／または $1: 1$ 付加体の脱炭酸を経てさらにもら1分子のマレイミドが付加した $1: 2$ endo-endo 付加体 [2]を得, 反応を解析した。すなわち，2-ピロン-5-カルボン酸メチル (MP) の場合は[1]のみが得られ，2-ピ ロン (P) および 4, 6-ジメチル-2-ピロン-5-カルボン酸エチル (EP) の場合は［1]と［2]が得られ， 4,6-ジメチル-2-ピロン (DMP) の場合は〔2]のみが得られた。これらのマレイミド類との反応性は $\mathrm{DMP}>\mathrm{P} \geqq \mathrm{EP}>\mathrm{MP}$ の傾向にあるので, 電子求引性な 5-エトキシカルボニル基の反応抑制効果は逆の 性質の 4,6-ジメチル基の反応促進效果より大きいのであろう。しかし, 電子不足の MP の反応性は, $N$-フリールマレイミドの $p$-位に，電子求引性の基よりも電子供与性の基がつくとき大きかった。この ことは 2-ピロンの 5-位メトキシカルボニル基はマレイミド類との反応でさえ逆電子要求型 $[4+2]$ 環 状付加反応を行なわせていることを示し, 分子軌道計算からも支持された。〔1]の熱安定性は 2-ピ口 ン環につく電子求引性基により增加するがメチル置換基により大きく減少することがわかった。

\section{1 楮言}

2-ビロン類の Diels-Alder(DA) 付加反応はコルヒチン1)やバ レレン2゙などの合成に利用されている。しかしその DA 反応はピ ロン環が芳香族性をるつために容易には起こりにくく，一方, 生 成した $1: 1$ 付加体は容易に脱炭酸および脱水素するために 2-ピ ロンを用いた合成反応の利用はかぎられている。またその DA 反応性および付加体の安定性に対する因子は詳細には検討されて いない状況にある。そこで 2-ピロン類の DA 反応性，付加体の 立体化学および熱安定性に関する瞋換基効果を明らかにすること とした。著者らは 2-ピロン類の熱および光環化付加による合成 化学的展開を検討中であるが3)，そのなかで p-ベンゾキノンとの DA 付加体の安定性に対する 2-ピロン体の置換基, 反応温度打 よひ溶媒の極性の効果を一部明らかにした ${ }^{8 a) 。 2-ヒ ゚ ロ ン-5-カ ル ~}$ ボン酸メチル（以下 MP と略記する）はエチルビニルエーテルと 室温であ収率よく DA 付加体を与えることを報告している3c)。 本報の結果を入れることにより 2-ピロン体の DA 反応に関する 総合的理解が得られる。

鹿児島大学工学部応用化学科, 890 鹿児島市郡元

1) J.Schreiber, W. Leimgruber, M. Pesaro, P. Schudel, T. Threlfall, A. Eschenmoser, Helv. Chim. Acta, 44, 540(1961).

2) H.E. Zimmerman, G. L. Grunewald, R. M. Paufler, M. A. Sherwin, J. Am. Chem. Soc., 91, 2330(1969).

3） a ）下茂徽朗，染川䖺一，涱元実忠，日化，1982，1927.

b ）下茂微朗, 染川緊一, 隈元実忠, 日化, 1983，394.

c）下茂徹朗，染川㹂一，佐藤光籍，故隈元実忠，日化， 1984, 1927.

\section{2 結 果亡考察}

\subsection{Diels-Alder 反応生成物}

2-ピロン体として 2-ピロン-5-カルボン酸メチル(MP)，2-ピ ロン(P)，4，6-ジメチル-2-ピロン-5-カルボン酸エチル(EP) 㧤 よび 4,6-ジメチル-2-ピロン(DMP) を用い， $N$-置換マレイミド 4 種之の反応を比較的低い温度 $\left(80 \sim 140^{\circ} \mathrm{C}\right)$ で行ない, 得られた 生成物を図式 1 と表 1 に示した。MP のときはタイプ〔1〕のそ れぞれ単一な生成物 $[1 \mathrm{a}] \sim[1 \mathrm{~d}]$ が得られ，Pおよび EP のと きはそれぞれ同様の [1e $] \sim[1 \mathrm{i}]$ とタイプ[2]の [2 $\mathrm{e}] \sim[2 \mathrm{j}]$ が得られた。DMP との反応はマレイミド技び $N$-フェニルマ レイミドとの間で行ない,それぞれタイプ〔2〕の[2k]，〔21] だけを高収率で得た。

タイプ〔1〕の 1:1 endo 付加体の棈造は元素分析, IR おょ び表 2 の ${ }^{1} \mathrm{H}-\mathrm{NMR}$ データを既報 ${ }^{3 \mathrm{Q}) 4)}$ および文献 ${ }^{51}$ と比較して結 論された。すなわち，[1 b $]^{5 \mathrm{a})}$ と $[1 \mathrm{f}]^{5 \mathrm{~b})}$ はすでに endo 体と報 告されており，それらが endo 体と判断された根拠のスピン結合 定数 $J_{1.9}$ および $J_{4.5}$ の值が他の〔1〕の化合物でも $4 \sim 5 \mathrm{~Hz}$ と endo 体に相当する大きな值である ${ }^{5 \mathrm{c})}$ 。また $[1 \mathrm{a}] \sim[1 \mathrm{~h}]$ の 5-

4）染川䝨一，渡辺典文，郎元実忠，日化，1978，412.

5) a) N.P.Shusherina, T. L. Nesterova, O. V. Polyakova, Zh. Org. Khim., 16, 1285(1980).

b) M. V. Gapeeva, A. U. Stepanyants, N.P. Shusherina, Yu. A. Knirel, R. Ya. Levina, Zh. Org. Khim., 7, 2426(1971).

c) N.P. Shusherina, M. H. Hakimi, A. U. Stepanyants, I. V.Zlokazova, Zh. Org. Khim., 13, 854 (1977). 


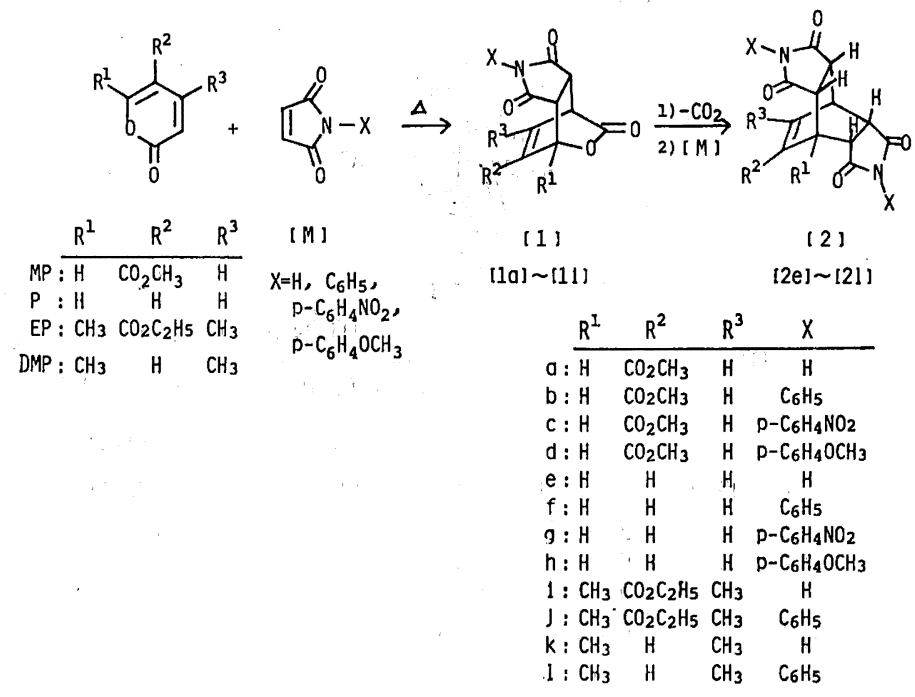

Scheme 1

Table 1 Reaction results of 2-pyrones with maleimides

\begin{tabular}{|c|c|c|c|c|}
\hline \multirow[b]{2}{*}{ 2-Pyrone } & Reaction & \multirow{2}{*}{ Solvent ${ }^{a)}$} & \multirow{2}{*}{$\begin{array}{l}\text { Time } \\
\text { (h) }\end{array}$} & \multirow{2}{*}{$\begin{array}{c}\text { Product } \\
(\%)\end{array}$} \\
\hline & Maleimide $(\mathrm{X})^{\mathrm{b}\}}$ & & & \\
\hline $\mathrm{a}: \mathrm{MP}$ & (H) & $\mathrm{T}$ & 5 & {$[1 \mathrm{a}] 48$} \\
\hline $\mathrm{b}: \mathrm{MP}$ & $\left(\mathrm{C}_{6} \mathrm{H}_{5}\right)$ & B & 24 & {$[1 \mathrm{~b}] 40$} \\
\hline $\mathrm{c}: \mathrm{MP}$ & $\left(p-\mathrm{C}_{6} \mathrm{H}_{4} \mathrm{NO}_{2}\right)$ & B & 29 & {$[1 \mathrm{c}] 14$} \\
\hline $\mathrm{d}: \mathrm{MP}$ & $\left(p-\mathrm{C}_{6} \mathrm{H}_{4} \mathrm{OCH}_{3}\right)$ & B & 12 & {$[1 \mathrm{~d}] 19$} \\
\hline $\mathrm{e}: \mathrm{P}$ & (H) & $T$ & 5 & {$[1 \mathrm{e}] 30,[2 \mathrm{e}] 54$} \\
\hline \multirow[t]{2}{*}{$f: P$} & $\left(\mathrm{C}_{6} \mathrm{H}_{5}\right)$ & $\mathrm{T}$ & 5 & {$[1 \mathrm{f}] 75,[2 \mathrm{f}] 0.6$} \\
\hline & & $\mathrm{X}$ & 12 & {$[2 \mathrm{f}] 57$} \\
\hline \multirow[t]{2}{*}{$g: P$} & $\left(p-\mathrm{C}_{6} \mathrm{H}_{4} \mathrm{NO}_{2}\right)$ & A & 13 & {$[1 \mathrm{~g}] 26$} \\
\hline & & $\mathrm{X}$ & 11 & {$[2 \mathrm{~g}] 61$} \\
\hline$h: P$ & $\left(p-\mathrm{C}_{6} \mathrm{H}_{4} \mathrm{OCH}_{3}\right)$ & A & 38 & {$[1 \mathrm{~h}] 54, \quad[2 \mathrm{~h}] 1$} \\
\hline $\mathrm{i}: \mathrm{EP}$ & (H) & $\mathrm{T}$ & 5 & {$[1 \mathrm{i}] 3,[2 \mathrm{i}] 73$} \\
\hline $\mathrm{j}: \mathrm{EP}$ & $\left(\mathrm{C}_{6} \mathrm{H}_{5}\right)$ & $\mathrm{T}$ & 5 & {$[2 \mathrm{j}] 75$} \\
\hline $\mathrm{k}: \mathrm{DMP}$ & $(\mathrm{H})$ & $\mathrm{T}$ & 5 & {$[2 \mathrm{k}] 91$} \\
\hline $1: \mathrm{DMP}$ & $\left(\mathrm{C}_{6} \mathrm{H}_{5}\right)$ & $\mathrm{T}$ & 5 & [21] 89 \\
\hline
\end{tabular}

a) All the reactions were carried out under reflux.

A : Acetonitrile, B : Benzene, $\mathrm{T}:$ Toluene, $\mathrm{X}:$ Xylene.

b) $\mathrm{N}$-Substituent of maleimides.

Hの化学シフトが 9-H よりすべて $0.3 \mathrm{ppm}$ 程度高傢場側にあ り，3-位カルボニル基の異方性効果で同様の值を与えている $N$ メチル-2-ピリドンとマレイミド類との endo 付加体 (exo 体む同 時に生成）のデーダからも endo 体として矛盾なく説明される。 一方，〔1 i〕の 9-H の高磁場側へのいずれも同じ文献から，1-位 メチル基の效果として説明され，〔1 i 〕 endo 体と判断される。 タイプ〔2〕は表 3 の分析データから, P, EP または D MP とマレイミド類との脱炭酸をともなった DA 型の $1: 2$ 付加体で ある。その立体棈造は, ${ }^{1} \mathrm{H}-\mathrm{NMR}$ データで [2 e], [2f]の2$\mathrm{H}, 6-\mathrm{H}, 8-\mathrm{H}$ および 12-H の 4 個のプロトンが等価であり，ま た [2i]〜[21]の 2-H と 12-H，6-H と 8-H がそれぞれ等価 であることから対称面をもつ endo-endo 型と判断される。なお この構造は Alder 則扰よび立体障害に関する分子模型の考察か らも示唆されるものである。

\subsection{2-ピロン類とマレイミド類との反応性と DA 付加体の熱} 安定性

2-ピロン類の DA 反応性についてはビス(トリメチルスタンニ ル)アセチレンとの煬合 MP》5-メチル-2-ピロン>P と報告され た文献もあり ${ }^{6}$ ，電子的効果が理解されていなかった。そこで MP， P， EP，DMP とマレイミドとの反応性を比較するために, 10 倍過剩のマレイミドを用いトルェン還流 1 時間の反応を行な い,ガスクロマトグラフィーで2-ピロン類の減少率を求めた。そ の結果 2-ピロン類の減少率は MP 20\%，P 34\%， EP 31\%, DMP $42 \%$ であったことから、マレイミドに対する 2-ピロン類 の反応性は $\mathrm{DMP}>\mathrm{P} \geqq \mathrm{EP}>\mathrm{MP}$ といえる。ここで EP の 5-エ トキシカルボニル基の電子求引性の大きさは 4,6-ジチル基の 電子供与性より大きいとみると，電子豊富な 2-ピロン体ほど DA 反応性が高かったといら結果であり, 電子効果は通常型の

6) A.B.Evnin, D. Seyferth, J.Am. Chem. Soc., 89, 952(1967). 
Table 2 Spectral data of [1]

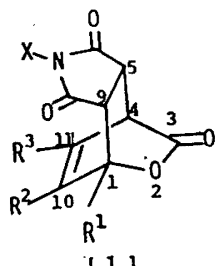

Compound

$\left(R^{\mathbf{1}}, \mathbf{R}^{\mathbf{2}}, \mathbf{R}^{\mathbf{3}}, \mathrm{X}\right)$

[1 a]

$\left(\mathrm{H}, \mathrm{CO}_{2} \mathrm{CH}_{3}, \mathrm{H}, \mathrm{H}\right.$ )

[ $1 \mathrm{~b}]$

$\left(\mathrm{H}, \mathrm{CO}_{2} \mathrm{CH}_{3}, \mathrm{H}, \mathrm{C}_{6} \mathrm{H}_{5}\right.$ )

[1 c]

$\left(\mathrm{H}, \mathrm{CO}_{2} \mathrm{CH}_{3}, \mathrm{H}, p-\mathrm{C}_{6} \mathrm{H}_{4} \mathrm{NO}_{2}\right.$ )

[ld]

$\left(\mathrm{H}, \mathrm{CO}_{2} \mathrm{CH}_{3}, \mathrm{H}, p-\mathrm{C}_{6} \mathrm{H}_{4} \mathrm{OCH}_{3}\right)$ [1 e]

(H, H, H, H)

[l f]

$\left(\mathrm{H}, \mathrm{H}, \mathrm{H}, \mathrm{C}_{6} \mathrm{H}_{5}\right.$ )

[1 $\mathrm{g}$ ]

$\left(\mathrm{H}, \mathrm{H}, \mathrm{H}, p-\mathrm{C}_{6} \mathrm{H}_{4} \mathrm{NO}_{2}\right)$

[1h]

$\left(\mathrm{H}, \mathrm{H}, \mathrm{H}, p-\mathrm{C}_{6} \mathrm{H}_{4} \mathrm{OCH}_{3}\right.$ )

[1i]

$\left(\mathrm{CH}_{3}, \mathrm{CO}_{2} \mathrm{C}_{2} \mathrm{H}_{5}, \mathrm{CH}_{3}, \mathrm{H}\right)$
IR

$\left(\mathrm{cm}^{-1}\right)$

1771,1721

1775, 1722

1777,1721

1773,1721

1785,1719

1754,1709

1751, 1715

1778,1710

1785,1765

1730,1700

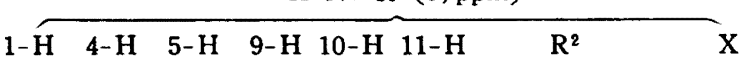

Coupling const., $J(\mathrm{~Hz})$

$\begin{array}{lllllll}5.84 & 4.05 & 3.62 & 3.86 & 7.46 & 3.72\end{array}$

$J_{1.9}=4.6, \quad J_{1.11}=2.5, \quad J_{4,5}=3.6, \quad J_{4,11}=5.8, \quad J_{5}=8.0$

7. $38 \quad 3.76$

$J$

$J_{1,8}=5.0, \quad J_{1,11}=2.5, J_{4.5}=3.5, J_{4,11}=6.0, J_{5.8}=8.0$

$\begin{array}{lllllllll}6.10 & 4.27 & 3.54 & 3.90 & 7.42 & 3.79 & 6.96,3.82 & \mathrm{CDCl}_{3}\end{array}$

$J_{1,9}=4.0, J_{1,11}=2.0, J_{45}=4.0, J_{4.11}=5.5, \quad J_{5.8}=8.0$

$\begin{array}{llllll}5.76 & 4.27 & 3.71 & 4.02 & 6.68 & 9.75\end{array}$

$J_{1,10}=J_{1.11}=J_{4.5}=4.0, \quad J_{1,9}=4.5, \quad J_{4.10}=J_{4.11}=3.6, \quad J_{5,9}=8.0$

$\begin{array}{lllll}5.85 & 4.37 & 3.84 & 4.12 & 6.79\end{array}$

$7.65,7.05$

$J_{1,10}=J_{1,11}=J_{4,10}=J_{4,11}=3.0, J_{1,9}=5.0, J_{4,5}=4.0, \quad J_{5,9}=8.0$

$\begin{array}{lllll}6.00 & 4.49 & 3.95 & 4.26 & 6.93\end{array}$

$8.48,7.56$

$J_{1,10}=J_{1,11}=4.0, \quad J_{1,9}=5.5, \quad J_{4,10}=J_{4,11}=J_{4,5}=3.5, \quad J_{5,9}=8.0$

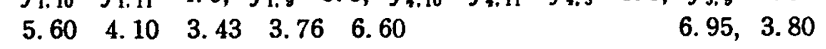

$J_{1.10}=J_{1.11}=J_{4,5}=4.0, \quad J_{1.9}=4.5, \quad J_{4,10}=J_{4,11}=3.5, \quad J_{5.9}=8.5$

$\begin{array}{llll}1.98 & 3.78 & 3.66 & 3.42\end{array}$

$1.834 .18,1.2011 .53$

(1.83)

(1.98)

Solvent

$J_{4.5}=3.5, J_{59}=8.0$

Table 3 Spectral data of [2]

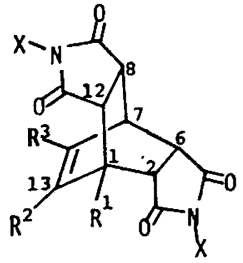

121

\section{IR}

$\left(\mathrm{cm}^{-1}\right)$

\begin{tabular}{|c|c|c|c|c|c|}
\hline$-\mathrm{H} \quad 12-\mathrm{H}$ & $6-\mathrm{H}$ & 8-H & 7-H & $R^{1}$ & \\
\hline
\end{tabular}

${ }^{1} \mathrm{H}-\mathrm{NMR}(\boldsymbol{\delta}, \mathrm{ppm})$

Coupling const., $\mathrm{J}(\mathrm{Hz})$

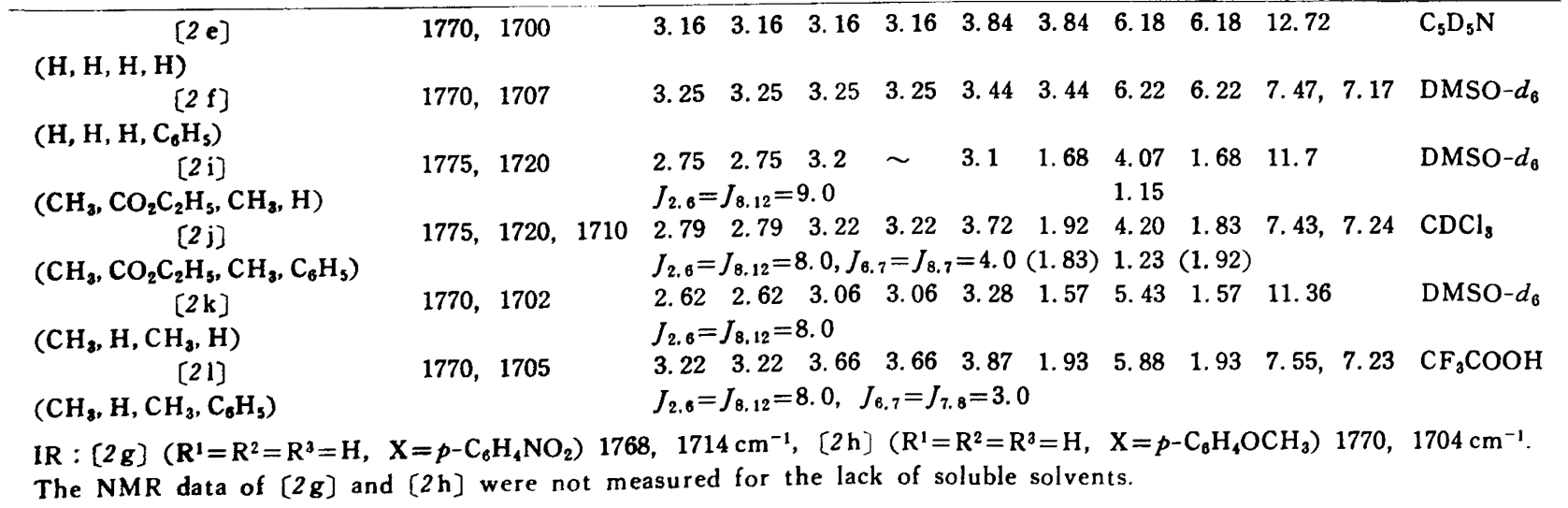




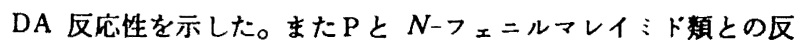
応結果 (キシレン中, 11 時間：〔2f] $(55 \%),[2 \mathrm{~g}](61 \%)$, [2 h] $(44 \%)$ ) 趽换基の電子求引性効果, $p-\mathrm{C}_{6} \mathrm{H}_{4} \mathrm{NO}_{2}>\mathrm{C}_{6} \mathrm{H}_{5}>$ $p-\mathrm{C}_{6} \mathrm{H}_{4} \mathrm{OCH}_{3}$ が原因していると考えられ，同棁の DA 反応性で ある。

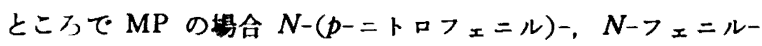
および $N$-( $p$-メトキシフェニル)マレイミドとの反応性について は，表1では反応条件が異なっていたので，トルェン這流 6 時間 の反応を行ないガスクロマトクラフィーで MP の減少で求めた。 その結果 MP の減少率はそれぞれ $17 \%, 21 \%, 28 \%$ であり，す なわち，反応性は $p-\mathrm{C}_{6} \mathrm{H}_{4} \mathrm{OCH}_{3}>\mathrm{C}_{8} \mathrm{H}_{5}>p-\mathrm{C}_{6} \mathrm{H}_{4} \mathrm{NO}_{2}$ となり圈換 基効果が上記の場合とは逆転した。この結果は，MP の逆䉓子要 求型 DA 反応性 ${ }^{8 c}$ を考罢し分子軌道法からつきのよ5に説明さ れる。すなわち，Hückel 法”で MP，と3 種類の $N$-フリールマ レイミドとの HOMO-LUMO 作用のエネルギー差はいずれる $0.78 \beta$ 程度と見積られた。一方，LUMO(MP)-HOMO(マレイ ミト類）作用はマレイミドの $p$-メトキシフェニル体の場合 $0.56 \beta, フ ェ ニ ル$ 体の場合 $0.90 \beta$ 扰よび $p$-ニトロフェニル体で $0.94 \beta$ と見積られ, 上記の反応性の順であり， $p$-メトキシフェ= ル体との組み合わせでは挠者の相互作用が大きいことが示唆され た。このよらなことから MP とマレイミド類との反応では HOMO-LUMO と LUMO-HOMO のエネルギー差は接近して おり両作用が反応を支配していると判断される。

以上のように，2-ピロン体の DA 反応において 5-位のメトキ シカルボニル基 1 個だけで 2 組の HOMO-LUMO 相互作用の大 きさの逆転を引き起こし得て, DA 反応性が変化することが示唆 された。文献 6 の現象す同栚にして考えることができる。すなわ ち，MP は電子豊富なアセチレンと逆触子要求型の DA 反応を し, 一方，5-メチル-2-ピロンは少なくとも通常の DA 反応性を 示す HOMO-LUMO 相互作用が主要の役割をしたとして解积さ れる。

つぎに DA 付加体の安定性について 2-ピロン類とマレイミト 類との反応においては，MP ではタイプ〔1〕の 1:1 付加体だ け，Pおよび EP では[1]とタイフ〔2]の $1: 2$ 付加休，ま た高温ではタイブ〔2〕たけ，DMP ではタイブ〔2〕だけが生 成し，DMP とのタイブ〔1〕の生成物は $80^{\circ} \mathrm{C}$ の反応条件下て あ得られなかった。これらのことからタイブ〔1〕の熱安定性は 2-ピロン環の固換等で左右され，5-位に電子求引性が存在すると 增大するといえる。しかし，〔1]と〔2] の生成比 [1]/[2] が，PょりもEP の場合にはるかに小さかったことから，DA 反 応性の場合と逆転して，4，6-ジメチル基による〔1〕の不安定化 効果の方か５-エトキシカルポニル基の安定化効果より大きかっ たと判断される。このよらな圈換基効果はつきのよらに説明され る。まず 2-ピロンの 5-位アルコキシカルボニル基の奻果につい ては二重結合の消失した 2-オキサビンクロ[2.2.2]オクタン-3-

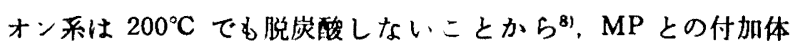
[1]の場合には 10-位フルコキシカルボ二ル基が $\mathrm{C}_{10}-\mathrm{C}_{11}$ 二重結 合との共役によりその二重結合性を減少させるとともに（図式 2)，その電気陰性によって $\mathrm{C}_{3}-\mathrm{C}_{4}$ および $\mathrm{C}_{1}-\mathrm{O}_{2}$ 結合をる幾分イ

7）時田澄男，富永信秀，“BASIC に上る分子軌道法計算入 門”，共立出版（1987）のバラメーターを用いた。

8) N.P. Shusherina, Russ. Chem. Rev., 43, 851(1974).

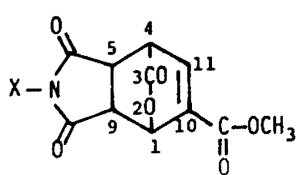

. [1a] [1d]

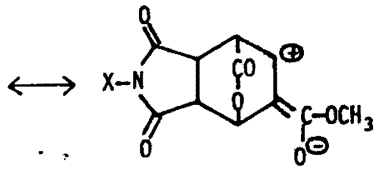

$[10]^{\prime} \sim[1 d] \cdot$
Scheme 2

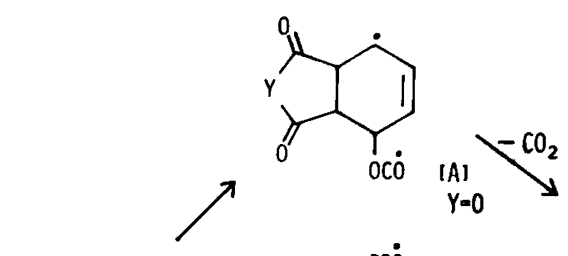

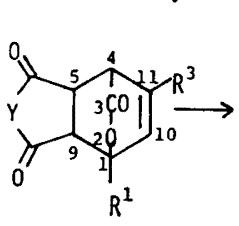

[1]

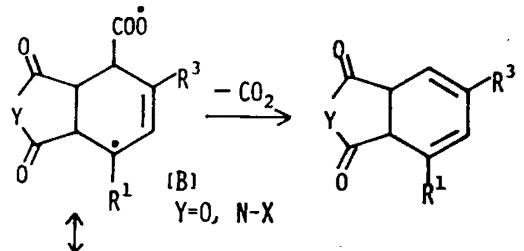<smiles>[R]C1=CC([Y])C([O])C2C(=O)NC(=O)C12</smiles>

Scheme 3

オン化し強くする作用があり安定化する。なお，2-ピロンDA 反 分物の熱安定性についてつぎのよらな文献がある。まず Goldstein らは 2-ピロンと無水マレイン酸との $1: 1$ 付加体の脱炭酸 は図式 3 の〔A]をへる 2 段階の分解反応であると推定してい る9。一方, Shusherina は 6-圆換 2-ビロン類と繁水マレイン酸 との $1: 1$ 付加体の不安定性について脱炭酸の要移状態を〔B]

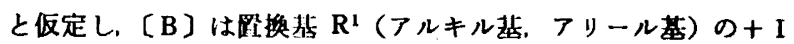
または+M效果により安定化され，脱炭酸が促進されると哾明し ている ${ }^{8)}$ 。DMP とPの付加体の安定性の差は上記の文裁 8,9 お よび本報の結果を入れて考察するとつぎよ5に解积される。ま ず，2-ピロン類との [4+2] 付加体はその分子模型より $\angle \mathrm{C}_{1}-\mathrm{C}_{10^{-}}$ $\mathrm{C}_{11}$ かi $110^{\circ}$ 程度の $\mathrm{sp}^{\mathrm{s}}$ 結合角に近いひずみをるった骨格であ り、脱炭酸は〔1]の $\mathrm{C}_{1}-\mathrm{O}_{2}$ または $\mathrm{C}_{3}-\mathrm{C}_{1}$ 結合のいずれかの開 裂を律速過程とする分解反店と考えられる。そこで DMP の付加 体の場合は，まず， $\mathrm{C}_{1}-\mathrm{O}_{2}$ 結合の開裂により生じたラジカルが 2 種のメチル基による超共役の効果で安定化され（[B]，[C]). 脱炭酸か，Pの付加体の場合よりも起こりやすくなったと判断さ れる。また，11-位メチル基は $\mathrm{C}_{10}-\mathrm{C}_{11}$ 二重結合との超共役でその 二重結合性を減少させる效果る考えられるか，むしろその奄子供 与性のために MP の 10-位フルコキシカルボニル基の場合とは 逆に $\mathrm{C}_{4}-\mathrm{C}_{4}$ および $\mathrm{C}_{1}-\mathrm{O}_{2}$ 結合を弱めろ作用が大きいものと考察 される。一方，マレイミドの $N$-位睓喚基Xによる付加体の安定 性への奻果は比較的小さかった。Xから問題の結合まで遗いので その電子的性貿の変化の影筑が小さいのであろう。

このよ5に2-ピロン体とマレイミドとの DA 反応においては

9) M. J. Goldstein, G. L. Thayer, Jr., J. Am. Chem. Soc., 87, 1933(1965). 
その 4,6-位メチル基は付加反応性を促進させる一方で付加体の 安定性を低下させ，5-位アルコキシカルボニル基は反応性を低下 させるがその付加体を安定化させることがわかり，また，両方の 基をすつ 2-ピロンでは反応性および付加体の安定体がそれらの 固換基により微妙に影整されることがわかった。これらの解析 は，2ーピロン体を用いる合成反応の分子設計のらえで示唆を与え るすのと思われる。

\section{3 実験}

\section{1 試 料}

$\mathrm{MP}, \mathrm{P}, \mathrm{DMP}$ (既報 ${ }^{3 \mathrm{a})}$ と同様にして合成し, EP(0a)，N-フェ ニルマレイミド10b) $N$-(p-メトキシフェニル)マレイミド100)は文 献により合成し、マレイミドは市販特級品を使用した。

\subsection{2-ピロン類とマレイミド類との反応と生成物の分離} 2-ピロン類 $(0.48 \sim 2.88 \mathrm{~g})$ に対し 1.0〜1.2 倍モルのマレイ ミド類を加え溶媒中（ペンゼン，フセトニトリル，トルエン，キ シレン) で 5 49 時間還流した。生成物はすへて結晶として得ら れ、エタノール，水などの溶媒から再結晶した。生成物の融点は 末補正值であり，分析機器は既報学) と同様である。

3.2.1 MP とマレイミトとの反応 (a) : MP $1.54 \mathrm{~g}(10$ $\mathrm{mmol})$ とマレイミド $1.16 \mathrm{~g}(12 \mathrm{mmol})$ のトルェン $20 \mathrm{ml}$ 溶液 を 5 時間還流し，析出した固体を水から再結晶して白色針状晶

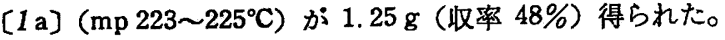

[1a]

分析值 C $52.63 \%$, H $3.63 \%$ ， N $5.55 \%$

$\mathrm{C}_{11} \mathrm{H}_{9} \mathrm{NO}_{6}$ としての

計算値 C $52.59 \%$ ， H $3.59 \% ， N 5.58 \%$

MS $(m / z): 252\left(6 \%, \mathrm{M}^{+}\right), 105\left(100 \%, \mathrm{C}_{7} \mathrm{H}_{5} \mathrm{O}^{+}\right)$

3.2.2 MP と $N$-フェニルマレイミドとの反応 (b) : MP $1.54 \mathrm{~g}(10 \mathrm{mmol})$ と $N$-フェニルマレイミド $1.73 \mathrm{~g}(10 \mathrm{mmol})$ のペンセン $15 \mathrm{ml}$ 溶液を 24 時間邉流し, 析出した固体をクロロ ホルムから再結晶して $[1 \mathrm{~b}]\left(\mathrm{mp} 155 \sim 160^{\circ} \mathrm{C}\right.$, 文献値 $\left.{ }^{5 \mathrm{~B}}\right)$ 148 $150^{\circ} \mathrm{C}$ ) が $1.3 \mathrm{~g}$ (収率 $40 \%$ ) 得られた。

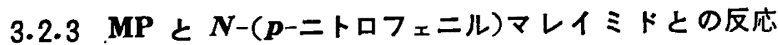

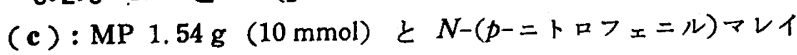
ミト $2.2 \mathrm{~g}(10 \mathrm{mmol})$ のペンゼン $26 \mathrm{ml}$ 溶液を 29 時間還流し. 析出した固体をェタノールーフセトン (1:1) から再結晶して白 色結晶 (1 c 〕 (mp 193 196 ${ }^{\circ} \mathrm{C}$ ) が $0.52 \mathrm{~g}$ (収㷅 14\%) 得られ た。

[1 c]

分析値 C $54.92 \% ， \mathrm{H} 3.39 \% ， \mathrm{~N} 7.38 \%$

$\mathrm{C}_{17} \mathrm{H}_{12} \mathrm{~N}_{2} \mathrm{O}_{3}$ としての

部算値 C $54.86 \% ， \mathrm{H} 3.22 \% ， \mathrm{~N} 7.52 \%$

MS $(m / z): 372\left(4 \%, \mathrm{M}^{+}\right), 105\left(100 \%, \mathrm{C}_{7} \mathrm{H}_{5} \mathrm{O}^{+}\right)$

3.2.4 MP と $\boldsymbol{N}$-(p-メトキシフェニル)マレイミトとの反応

10) a) N. R. Smith, R.H.Wiley, "Organic Syntheses", Coll. Vol. IV, John Wiley and Sons, Inc., N. Y., p. 549(1963).

b) M.P. Cava, A. A. Deana, K. Muth, M. J. Mitchell, "Organic Syntheses", Coll. Vol. V, John Wiley and Sons, Inc., N. Y., p. 944(1973).

c) W. R. Roderick, J. Am. Chem. Soc., 79. 1710 (1957).

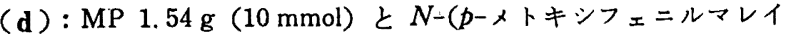
ミド $2.0 \mathrm{~g}(10 \mathrm{mmol})$ のベンセン $7 \mathrm{ml}$ 溶液を 12 時問還流し, 析出した固体をアセトンから再結晶して白色結晶 [ $1 \mathrm{~d}](\mathrm{mp} 192$ $\left.\sim 195^{\circ} \mathrm{C}\right)$ が $0.68 \mathrm{~g}(19 \%)$ 得られた。

[1d]

分析值 C $60.47 \%, \mathrm{H} 4.22 \%$ N $3.95 \%$

$\mathrm{C}_{18} \mathrm{H}_{15} \mathrm{NO}_{7}$ としての

計算值 C $60.50 \%, \mathrm{H} 4.23 \%, \mathrm{~N} 3.92 \%$

MS $(m / z): 357\left(85 \%, \mathrm{M}^{+}\right), 149\left(100 \%, \mathrm{C}_{8} \mathrm{H}_{7} \mathrm{NO}_{2}{ }^{+}\right)$

3.2 .5 Pとマレイミドとの反応 (e) : P $2.88 \mathrm{~g}$ (30 mmol) と マレイミト゚ $2.91 \mathrm{~g}(30 \mathrm{mmol})$ のトルエン $20 \mathrm{ml}$ 溶液を 5 時間還 流し，析出した固体の熱アセトン不溶部から白色粉末〔2 e〕 $\left(\mathrm{mp}>300^{\circ} \mathrm{C}\right.$ ) が $2.0 \mathrm{~g}$ (収率 $54 \%$ ) 得られた。アセトン沪液か ら析出した固体をメタノールから再結晶して白色針状晶 〔1 e (mp $180 \sim 181^{\circ} \mathrm{C}$ ) が $1.83 \mathrm{~g}$ (収率 $30 \%$ ) 得られた。

[1e]

分析值 C $55.97 \%$ Ｈ $3.69 \% ， \mathrm{~N} 7.29 \%$

$\mathrm{C}_{9} \mathrm{H}_{7} \mathrm{NO}_{4}$ としての

計算値 C $55.96 \%, \mathrm{H} 3.63 \%, \mathrm{~N} 7.25 \%$

[2e]

分析值 C $58.16 \%, \mathrm{H} 4.07 \%, \mathrm{~N} 10.99 \%$

$\mathrm{C}_{12} \mathrm{H}_{10} \mathrm{~N}_{2} \mathrm{O}_{4}$ としての

計算値 C $58.56 \% ， \mathrm{H} 4.06 \% ， \mathrm{~N} 11.38 \%$

3.2.6 P と $N$-フェニルマレイミドとの反応 (f) : P $1.9 \mathrm{~g}$

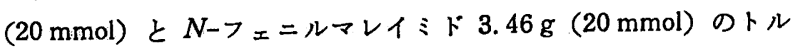
エン $5 \mathrm{~m} l$ 溶液を 5 時間還流し，析出した固体をメタノールから 再結晶すると $[1 \mathrm{f}]\left(\mathrm{mp} \mathrm{169} \sim 171^{\circ} \mathrm{C}\right.$, 文献値 $\left.{ }^{5 b} \quad 163 \sim 164^{\circ} \mathrm{C}\right)$ が $4.0 \mathrm{~g}$ (収率 $75 \%$ ) 得られた。トルェン沪液から析出した固体を クロロホルムから再結晶すると白色粉末 [2f] $\left(\mathrm{mp}>300^{\circ} \mathrm{C}\right)$ が $22 \mathrm{mg}$ (収率 $0.6 \%$ ) 得られた。この反応をキシレン還流で 12 時 間行ならと〔2f]のみが $57 \%$ の収率で得られた。

[2f]

分析值 C $72.07 \%, \mathrm{H} 4.47 \%, \mathrm{~N} 6.96 \%$

$\mathrm{C}_{24} \mathrm{H}_{18} \mathrm{~N}_{2} \mathrm{O}_{4}$ としての

計算值 C $72.36 \%, \mathrm{H} 4.52 \% ， \mathrm{~N} 7.04 \%$

3.2.7 P と $N$ - $(\boldsymbol{p}$-ニトロフェニル)マレイミドとの反応 $(\mathrm{g}):$

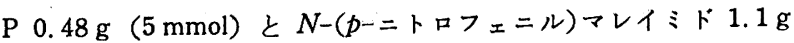
$(5 \mathrm{mmol})$ のアセトニトリル $10 \mathrm{ml}$ 溶液を 13 時間還流し析出 した固体をエタノールから再結晶すると淡黄色針状晶〔1 g] (mp $179 \sim 182^{\circ} \mathrm{C}$ ) が $0.41 \mathrm{~g}$ (収率 $26 \%$ ) 得られた。一方, $\mathrm{P} 0.96 \mathrm{~g}$

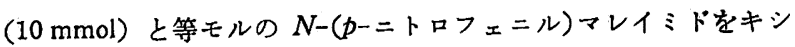
レン $50 \mathrm{~m} l$ 中で 11 時間還流し析出した固体をエタノールから再 結晶すると白色粉末 $[2 \mathrm{~g}]\left(\mathrm{mp}>300^{\circ} \mathrm{C}\right)$ か $1.5 \mathrm{~g}$ (収率61\%) 得 られた。

[1 g]

分析值 C $57.43 \%, \mathrm{H} 3.23 \%, \mathrm{~N} 8.91 \%$

$\mathrm{C}_{15} \mathrm{H}_{10} \mathrm{~N}_{2} \mathrm{O}_{6}$ としての

計算值 C $57.32 \% ， \mathrm{H} 3.19 \% ， \mathrm{~N} 8.92 \%$

$[2 \mathrm{~g}]$

分析値 C $59.05 \%, \mathrm{H} 3.32 \%, \mathrm{~N} 11.22 \%$

$\mathrm{C}_{24} \mathrm{H}_{16} \mathrm{~N}_{4} \mathrm{O}_{8}$ としての

計算值 C $59.02 \% ，$ H $3.28 \% ， \mathrm{~N} 11.48 \%$ 
3.2.8 P と $\boldsymbol{N}$-( $\boldsymbol{p}-$ メトキシフェニル)マレイミドとの反応 (h) : P $0.48 \mathrm{~g}(5 \mathrm{mmol})$ と $p$-(メトキシフェニル)マレイミド. $1.0 \mathrm{~g}(5 \mathrm{mmol})$ のアセトニトリル $10 \mathrm{ml}$ 溶液を 38 時間還流し て析出した固体をエタノールから分別再結晶すると白色針状晶

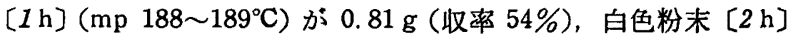
$\left(\mathrm{mp}>300^{\circ} \mathrm{C}\right.$ ) が $20 \mathrm{mg}$ (収率 $1 \%$ ) 得られた。この反応をキシレ ン還流で 11 時間行ならと,〔2 h〕のみが $44 \%$ の収率で得られ た。

[1 $\mathrm{h}]$

分析値 C $63.97 \%, \mathrm{H} 4.33 \%, \mathrm{~N} 4.64 \%$

$\mathrm{C}_{18} \mathrm{H}_{13} \mathrm{NO}_{5}$ としての

計算值 C $64.23 \%, \mathrm{H} 4.35 \%, \mathrm{~N} 4.68 \%$

[2h]

分析値 C $67.94 \%, \mathrm{H} 4.80, \mathrm{~N} 6.16 \%$

$\mathrm{C}_{26} \mathrm{H}_{22} \mathrm{~N}_{2} \mathrm{O}_{6}$ としての

計算值 C $68.14 \%, \mathrm{H} 4.80 \%, \mathrm{~N} 6.11 \%$

3.2.9 EP とマレイミドとの反応（i）: EP $1.96 \mathrm{~g}$ (10 $\mathrm{mmol})$ とマレイミド $0.97 \mathrm{~g}(10 \mathrm{mmol})$ のトルェン゙ $10 \mathrm{ml}$ 溶腋 を 5 侍間還流し，析出した固体をアセトニトリルから再結晶して 無色透明針状晶 [2 i $\left(\mathrm{mp}>300^{\circ} \mathrm{C}\right.$ ) が $1.28 \mathrm{~g}$ (収率 $73 \%$ ) 得ら れた。汇液を浱維して得られた粘稠物のンリカダルカラムクロマ トグラフィー（展開溶煤：ベンゼンーフセトン (10:1)) から然色 透明針状晶 [ $[1 \mathrm{i}]\left(\mathrm{mp} 143 \sim 145^{\circ} \mathrm{C}\right.$ ) が $0.1 \mathrm{~g}$ (収率 $3 \%$ ) が得ら れた。

[1 i]

分析値 C $57.23 \%, \mathrm{H} 5.20 \%, \mathrm{~N} 4.77 \%$

$\mathrm{C}_{14} \mathrm{H}_{15} \mathrm{NO}_{6}$ としての

計算值 C $57.34 \%, \mathrm{H} 5.16 \%$ ，N $4.78 \%$

MS $(m / z): 293\left(0.1 \%, \mathrm{M}^{+}\right), 203(100 \%)$

[2i]

分析値 C $58.93 \%, \mathrm{H} 5.30 \%, \mathrm{~N} 8.11 \%$

$\mathrm{C}_{17} \mathrm{H}_{18} \mathrm{~N}_{2} \mathrm{O}_{6}$ としての

計算値 C $58.96 \%, \mathrm{H} 5.24 \%, \mathrm{~N} 8.09 \%$

MS $(m / z): 346\left(6 \%, \mathrm{M}^{+}\right), 300(100 \%)$

3.2.10 EP と $N-$ エェニルレイミトとの反応 $(\mathrm{j}): \mathrm{EP}$ $1.96 \mathrm{~g}(10 \mathrm{mmol})$ と $N$ エ ニルマレイミト $1.73 \mathrm{~g}(10 \mathrm{mmol})$ のトルエン $10 \mathrm{~m} l$ 溶液を 5 時間還流し, 析出した固体をトルェン から再結晶して無色透明針状晶〔2j〕（mp 292 295 ${ }^{\circ} \mathrm{C}$ ) が $1.87 \mathrm{~g}$ (収率 $75 \%$ ) 得られた。

[2 j]

分析値 C $70.03 \%, \mathrm{H} 5.30 \%, \mathrm{~N} 5.52 \%$

$\mathrm{C}_{28} \mathrm{H}_{28} \mathrm{~N}_{2} \mathrm{O}_{6}$ としての

計算値 C $69.87 \%$ ，H $5.26 \% ， \mathrm{~N} 5.62 \%$

MS $(m / z): 498\left(19 \%, \mathrm{M}^{+}\right), 66(100 \%)$

3.2.11 DMP とマレイミトとの反応 $(\mathbf{k}):$ DMP $1.24 \mathrm{~g}(10$ $\mathrm{mmol})$ とマレイミド $0.97 \mathrm{~g}(10 \mathrm{mmol})$ のトルェン $20 \mathrm{ml}$ 溶液 を 5 時間邊流し，析出した固体を酢酸から再結晶して白色結晶 [2 k] $\left(\mathrm{mp}>300^{\circ} \mathrm{C}\right.$ ) が $1.26 \mathrm{~g}$ (収率 $91 \%$ ) 得られた。

[2k]

分析値 C $60.83 \%, \mathrm{H} 5.39 \%, \mathrm{~N} 10.10 \%$

$\mathrm{C}_{14} \mathrm{H}_{14} \mathrm{~N}_{2} \mathrm{O}_{4}$ としての

計算値 C $61.30 \%$ ，H $5.14 \% ， \mathrm{~N} 10.21 \%$

MS $(m / z): 274\left(12 \%, \mathrm{M}^{+}\right), 106(100 \%)$

3.2.12 DMP $N-$ フェニルマレイミドとの反応 (1):

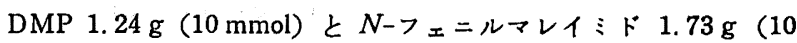
$\mathrm{mmol})$ のトルェン $20 \mathrm{ml}$ 溶液を 5 時間還流し，析出した固体を メタノールから再絬晶して無色透明板状晶〔21]（mp 265〜 $268^{\circ} \mathrm{C}$ ) が $1.9 \mathrm{~g}$ (収率 $89 \%$ ) 得られた。

[21]

分析值 C $72.90 \% ， \mathrm{H} 5.17 \%, \mathrm{~N} 6.69 \%$

$\mathrm{C}_{26} \mathrm{H}_{22} \mathrm{~N}_{2} \mathrm{O}_{4}$ としての

計算值 C $73.24 \% ， \mathrm{H} 5.16 \% ， \mathrm{~N} 6.57 \%$

3.32 -ビロン類とマレイミドとの反応种の測定

2-ピロン類として MP $77 \mathrm{mg}(0.5 \mathrm{mmol})$, P $48 \mathrm{mg}(0.5$ $\mathrm{mmol})$, EP $98 \mathrm{mg}(0.5 \mathrm{mmol}), \operatorname{DMP} 62 \mathrm{mg}(0.5 \mathrm{mmol})$, 10 倍モルのマレイミドとをトルェン $5 \mathrm{ml}$ 中で還流し, ガスクロ マトクララフィーで 2-ピロン類の減少量を定量して反応率とした。 $3.4 \mathrm{MP}$ と $\boldsymbol{N}-$ フェニルマレイミド類との反応率の測定

MP $50 \mathrm{mg}(0.3 \mathrm{mmol})$ と等モルの $N-$ エニルマレイミド類

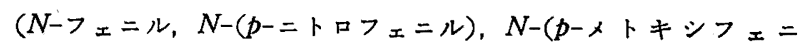
ル)体）とをトルェン $5 \mathrm{~m} l$ 中で還流し，ガスクロマトグラフィー で MP の減少量を定量して反応率とした。

本論文の作成にあたり有益な御教示を数きむした能本工業大学 柘檤乙彦教授に厚く御礼申し上げます。 


\title{
$[4+2]$ Cycloaddition Reaction of Substituted 2-Pyrones with Maleimides and Stability of the Adducts
}

\author{
Tetsuro Shimo, Hiroyuki Yoshimura, Takaaki Surshu \\ and Kenichi Somekawa* \\ Department of Applied Chemistry, Faculty of Engineering, Kagoshima University; \\ Korimoto, Kagoshima-shi 890 Japan
}

For the purpose of clarification of the factors influencing the Diels-Alder (DA) reactivity of 2-pyrones and the stability of the DA adducts, the DA reactions of four 2-pyrones with $\mathrm{N}$-substituted maleimides were investigated. Wher as the reactions of methyl 2-pyrone-5carboxylate (MP) with $N$-substituted maleimides only gave endo-DA adducts [ 1$]$, those of 2-pyrone (P) and ethyl 4,6-dimethyl-2-pyrone-5-carboxylate (EP) with the maleimides gave [1] and 1:2 endo-endo-DA adducts [2] which were formed through decarboxylation of the corresponding [4+2] adducts, followed by addition of another molecule of the maleimides. On the other hand, the reactions of 4,6-dimethyl-2-pyrone (DMP) afforded only [2] even under mild conditions.

The reactivity of 2-pyrones with maleimide diminished in order; DMP $>\mathrm{P} \geq \mathrm{EP}>\mathrm{MP}$, showing that electron-rich 2-pyrones are more reactive than the electron-defficient ones. However, the acceleration effect of 4,6-dimethyl groups seems to be smaller than the deceleration effect of 5-ethoxycarbonyl group. The reactivity of MP with $N$-substituted maleimides diminished by more electron-withdrawing $N$-substituents, suggesting that a 5 -methoxycarbonyl group on 2-pyrone makes the 2-pyrone an inverse electron-demand manner even in the reaction with maleimides.

The thermostability of $[1]$ was found to be enhanced by an electron-withdrawing substituent of 2-pyrone at 5-position and to be decreased by 4,6-dimethyl groups. 